\title{
NEUROVIRULENCE FOR RATS OF THE JHMV VARIANTS ESCAPED FROM NEUTRALIZATION WITH THE S1-SPECIFIC MONOCLONAL ANTIBODIES
}

\author{
Fumihiro Taguchi, Hideka Suzuki, Hiromi Takahashi, and Hideyuki Kubo \\ National Institute of Neuroscience, NCNP \\ 4-1-1 Ogawahigashi, Kodaira \\ Tokyo 187, Japan
}

\begin{abstract}
We have studied the neurovirulence for rats of the MAb-resistant variants isolated from a highly neurovirulent JHMV, cl-2. The variants, MM6 and MM13, with point mutation located within the $\mathrm{N}$ terminal 100 amino acids (aa) of the $\mathrm{S} 1$ protein showed no alteration in neurovirulence in comparison with cl-2, showing high neurovirulence. The variants, MM65 and MM85, with a deletion composed of about 150 aa located in the middle of the S1 subunit were revealed to be non-neurovirulent. A variant MM78 with one aa deletion, asparagic acid at number 543 from the $\mathrm{N}$ terminus of the $\mathrm{S} 1$, was shown to be low-virulence. The neurovirulence of these viruses paralleled with the viral growth potential in the rat brain. However, all of these variants as well as parental cl-2 showed high neurovirulence for mice. These results suggest that the domain composed of about 150 aa in the middle of the S1 is critical for high-neurovirulence of JHMV for rats.
\end{abstract}

\section{INTRODUCTION}

The spike (S) protein is suggested to be a major determinant of the neurovirulence of JHMV for mice ${ }^{1,2}$. The variant viruses escaped from neutralization of parental JHMV by the monoclonal antibodies (MAbs) specific for the S protein (MAb-resistant variants) have been revealed to have altered neurovirulence for mice ${ }^{3,4}$. The comparative nucleotide analyses of such variants and parental JHMV have identified the region on the S protein critical for the high neurovirulence for mice, although it is to be determined whether a single or multiple sites of the $\mathrm{S}$ gene are implicated with the neurovirulence ${ }^{5,6}$. However, it is not yet well studied on the viral factor influencing upon the neurovirulence of JHMV for rats, although it has been reported that JHMV variants with a large S protein are highly 
neurovirulent, while those with a small $S$ protein are not ${ }^{78}$ To analyze the role of the $S$ protein in neurovirulence for rats, we have obtained MAb-resistant variants after neutral1zation by MAbs specific for the $S$ protein By using those variants, we have tested whether the $\mathrm{S}$ protein is implicated with the neurovirulence for rats

\section{EXPERIMENTAL DESIGN AND RESULTS}

Variants obtained after neutralization by MAbs No 6, 13, 56, 78 and $85^{9}$ were designated MM6, MM13, MM56, MM78 and MM85, respectively The nucleotide sequencing analyses showed that MM6 and MM13 have point mutations at aa numbers 83 (Gly to Glu) and 26 (Asn to His) from the $\mathrm{N}$ terminus of the S protein, respectively MM56 and MM85 were shown to contain a deletion of a stretch composed of 153 and 151 aa, respectively MM78 contained only one aa deletion at the position of 543, asparagic acid

We studied the neurovirulence of these variant viruses selected with various MAbs After inoculation of $10^{5}$ PFU of variant viruses into the brain of 4 week old Lewis rats, MM6 and MM13 were demonstrated to be highly neurovirulent for rats as was their parental cl-2 About $80 \%$ of rats infected these viruses showed clinically central nervous symptoms within 12 days postinpculation $\left(\mathrm{p}_{1}\right)$ and most of these succumbed within 15 days The rats inoculated with MM65 and MM85 showed no clinical symptoms nor died during the observation period MM78 was shown to be intermediately virulent Highly virulent viruses, cl-2, MM6 and MM13 were revealed to grow well $\left(10^{3}\right.$ to $\left.10^{4} \mathrm{PFU} / \mathrm{g}\right)$ as compared with the avirulent MM56 or MM85 (<10 PFU/g) MM78 with intermediate virulence showed their titer in the brain intermediate $\left(10^{2}\right.$ to $\left.10^{3} \mathrm{PFU} / \mathrm{g}\right)$ between high- and non-neurovirulent viruses These results clearly showed that the neurovirulence of cl-2 and its variants correlated well with the growth potential in the brain of rats

We then examined the neurovirulence of our MAb-resistant viruses for BALB/c mice After inoculation of $10^{3} \mathrm{PFU}$ of cl-2, MM6, MM85 or MM78 with different neurovirulence for rats, there was no remarkable difference in the lethality and time to death of mice inoculated with each of these variants, showing clearly that there was no difference in neurovirulence for mice The difference in neurovirulence of JHMV observed in different laboratory ${ }^{56}$ may result from the some point mutations in the S proteins of MAb-resistant viruses isolated different laboratories or it may due to the unidentified viral genetic differences

The present study indicates that the neurovirulence of JHMV for rats is determined by the S protein of the virus, the JHMV variants with the larger S protein are highly virulent and those with the deleted S protein are low- or non-neurovirulent The neurovirulence of the viruses correlates with the viral growth potential in the rat brain Identification of cell types in the rat brain to support the replication of JHMVs with the larger S protein but not that of JHMVs with the deleted S protein is important to analyze the mechanisms underlining the neurovirulence of JHMV for rats

\section{REFERENCES}

1 Holmes, K V, E W Doller and J N Behnke Analysis of the function of coronavirus glycoprotein by differential inhibition of synthesis with tunicamycin Adv Exp Med Biol 1981,142 133-142

2 Spaan, W, D Cavanagh, and M C Horzınek Coronaviruses structure and genome expression J Gen Virol 1988,69 2939-2952

3 Dalziel, R G, P W Lampert, P J Talbot, and M J Buchmeier Site-specific alteration of murıne hepatitis virus type 4 peplomer glycoprotein E2 results in reduced neurovirulence J Virol 1986,59 463- 471 
4 Flemıng, J O , M D Trousdale, F A K El-Zaatarı, S A Stohlman, and L P Weıner Pathogenıcity of ant1genic variants of murine coronavirus JHM selected with monoclonal antibodies J Virol 1986,58 869-875

5 Parker, S E, T M Gallagher, and M J Buchmeier Sequence analysis reveals extensive polymorphism and evidence of deletions within the E2 glycoprotein gene of several strains of murıne hepatitıs virus Virology 1989,173 664-673

6 Wang, F-I, J O Flemıng and M MC Lai Sequence analysis of the spike protein gene of murıne coronavirus variants Study of genetic sites affecting neuropathogenicity Virology 1992,186 742-7491

7 Taguchı, F, S G Siddell, H Wege, and V ter Meulen Characterization of a variant virus selected in rat brain after infection by coronavirus mouse hepatitıs virus JHM J Virol 1985,54 429-435

8 Matsubara, Y, R Watanabe, and F Taguchı Neurovirulence of six different murıne coronavirus JHMV variants for rats Virus Res 1991,20 45-58

9 Kubo, H, S Y Takase, and F Taguchı Neutralızation and fusion inhibition activities of monoclonal antıbodies specific for the S1 subunit of the spike protein of neurovirulent murine coronavirus JHMV cl-2 variant J Gen Virol 1993,74 1421-1425 